\title{
Total Quality Management (TQM): A Catalyst for Service Delivery in the South African Police Service
}

\author{
REDDY, Michael
}

\section{Abstract}

Ceptember 2014 marked the release of the 2013/14 crime statistics in South Africa by the National Commissioner of the SAPS and the Minister of Police. Does a sense of safety and security fill the atmosphere? Do most South Africans, investors, and tourists alike believe that the crime rate in South Africa is reflective of a war zone and that South Africa is in a quagmire that engenders irretrievable damage to the lives of the citizenry and the economy? It is accepted that crime is a conflation of a number of economic, social and cultural factors; hence as a reviewable point, can the SAPS ensure the development of unassailable and perpetual policy solutions, underpinned with the highest quality that provides a guarantee of the citizen's basic constitutional right to freedom and life. This article reviews literature on TQM and extrapolates lessons learnt to the practical functioning of the SAPS with a view to provide a myriad of TQM principles that may be considered by SAPS Management; this could serve as a catalyst for an improved policing service in South Africa.

Keywords: Quality Management, service delivery, South African Police Service, Management. 


\section{Introduction}

The South African Government has adopted the National Development Plan (NDP) which provides the diagnostic and plan for eliminating poverty and reducing inequality by 2030. The plan encourages change, hardwork, leadership and unity to achieving this goal (NDP, 2011). Every government department is mandated to commit towards building a capable state. The SAPS has made several strides towards giving effect to the wishes of the NDP by, amongst others, increasing the number of police officials, improving recruitment policies and training programmes. The article strongly synthesizes the principles of TQM that could be applied through management processes ranging from customer focus to diffusion of feedback from clients, amongst other issues. In order to be used in a more constructive manner, SAPS membership need to aspire to have a common understanding on the application of the procedures and processes of TQM to ensure effective police service delivery.

This article is premised to present literature on the subject of TQM by explaining in broad viewpoints some principles, concepts, values and practices to be considered in the application of TQM in public service, with a sharp focus on the SAPS, which could serve as a policy-driven tool in the process of implementation of SAPS policing polices, projects and programmes.

It is also envisaged to deal expansively on the contribution made by Jablonski (1992) to the subject of TQM. This serves as a starting point for the implementation and substance of TQM in organisations which value customers and view quality products and services as the means of expanding their customer bases, as well as retaining and boasting customer loyalty. These approaches advanced in theory are examined in the SAPS context and finally provide practical recommendations to the SAPS for effective implementation of TQM across its areas of operation, thus improving service delivery standards and making South Africa a safer place for all to live in.

\section{Understanding the Philosophy of Total Quality Management}

Total Quality Management (TQM) is defined by the International Organisation for Standardisation (ISO), as a management approach for an organisation, centred success through customer satisfaction, and benefits to all members of the organisation and to society (ISO 8402: 1994). 
TQM, as a management solution, is the foundation of the following seven (7) activities, as depicted in Fig 1.

Figure 1: TQM AS A MANAGEMENT SOLUTION

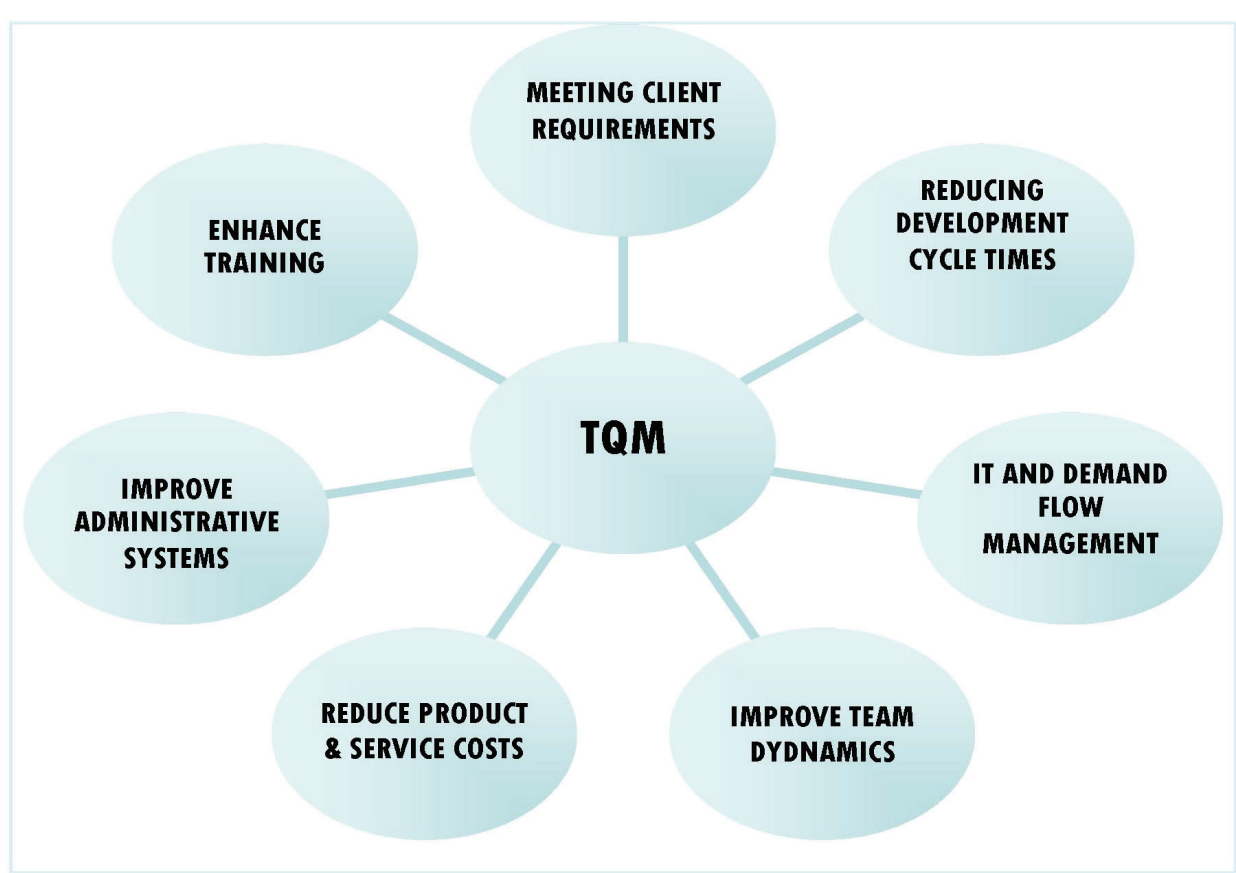

Unpacking TQM in detail reveals the following elements,

1) Total - quality involving everyone and all activities of an organisation;

2) Quality - the conforming to set requirements, i.e., meeting of customer requirements;

3) Management - quality can and must be managed.

In summary, TQM is thus a process of managing quality; involving a continuous way of life; a philosophy of perpetual involvement in everything one does (Hansen, 2008: 21). 


\section{Typical Management Functions in Organisations}

Smit and Cronje (2007: 14-15) suggest that management must execute the following seven (7) management functions effectively in organisations to ensure profitability and service excellence:

- The general management function: this involves the examination of the management process as a whole, including the planning that management has to do, the organisation that managers have to establish to enable them execute the plans, and the leadership that managers have to assume to get things done.

- The marketing function: this entails the marketing of products or services that the organisation offers and the formulation of the organisation's marketing strategy.

- The financial function: this covers the acquisition, utilisation and control of the financial resource that an organisation requires to finance its activities.

- The production or operation management function: this encompasses the group of activities concerned with the physical production of products, which involves the layout for the production process.

- The research and development function: this entails the development of new products and the improvement of the old product range; also including changes and improvements made to information technology and communications.

- The human resource function: this entails the appointment, development and the maintenance of human resources in any organisation; and

- The public relations function: this involves creating a positive and professional corporate image of the organisation.

To ensure the effective implementation of TQM in organisations, quality must be regulated across all management functions. While TQM has proven to be an effective process for organisational functioning, its value can only be assured through a comprehensive and well thought-out implementation process which must be carefully monitored and evaluated by management. 


\section{The Founding Fathers of Total Quality Management}

In the Western world, the four best quality management philosophers and experts are all Americans, viz. Crosby (1979), Deming (1982), Feigenbaum (1983) and Juran (1988). These four experts have contributed significantly on the development of TQM in organisations throughout the world, and their ideas and principles form the back-borne of a successful $21^{\text {st }}$ century organisation, regardless of whether it's in the private or public sector of any economy.

In addition to the contribution made by the Western philosophers, a significant publicity was received on the Japanese quality management culture. They include, Imai (1986), Ishikawa (1985), Mizuno (1988), Nemoto (1987), Ozeki and Askaka (1990), Shingo (1986) and Taguchi (1986). The ideas of the Japanese have been adopted and utilised in the Western world, with specific attention to managing processes of continuous improvement (Dale \& Bunney, 1999: 43).

\section{Edward Deming}

Among the experts alluded to, Edward Deming has been widely accepted as the main contributor of the implementation of the 'modern' TQM. He argued that quality through a reduction in statistical variation improves productivity and competitive position. His idea of quality assurance in management was guided by a set of 14 principles on management. The principles he advanced included the following:

- Create constancy of purpose towards improvement of products and services: this he argued should be done with the aim to become competitive, stay in businesses and create job opportunities.

- Adopt the new philosophy: management must be acutely aware of the changing future and adapt accordingly.

- Cease dependence on inspection to achieve quality: he advises strongly that quality should be initially built into the product, rather than depending on constant inspection to monitor quality. 
- End the practice of awarding business on the basis of price tag: he advises that costs can be minimized by moving towards a single supplier who can be contracted on a long term basis, through prolonged mutual trust and loyalty.

- Constantly improve the system of production and service: this involves the constant improvement of quality and decrease in costs.

- Institute on the job training: this ensures a system of continuous improvement and elimination of skills obsolescence for improved productivity.

- Institute leadership: he advises that management should offer support and assistance to people and machinery.

- Drive out fear: this is vital to enhance effectiveness in the workplace.

- Break down barriers between departments: this requires that all departments work as a cohesive whole (team players) so that problems can be detected and resolved timeously.

- Eliminate slogans, exhortations and targets for the workforce that ask for zero defects and new levels of productivity: this may cause adverse relationships, as the bulk of the causes of low quality and low productivity belong to the system and thus lies beyond the power of the workforce.

- Eliminate work standards (quotas) on the factory floor: he advances that leadership must be instituted instead.

- Remove barriers that rob the hourly worker of his/her right to pride of workmanship: the responsibility of supervisors must be shifted from crunching the numbers to quality.

- Institute a vigorous programme of education and self-improvement: this will enable a learning organisation which promotes individual improvement for organisational success; and

- Put everybody in the company to work to accomplish the transformation: the transformation is everyone's responsibility (Access: http://asq.org/learn-aboutquality/total-quality-management/overview/deming-points.html). Retrieved on 2014 - 09 - 01. 


\section{Joseph R Jablonski}

TMQ needs to have principles which serve as yardsticks and benchmarks through which TMQ compliant organisations have to abide and adhere to. These principles serve to ensure that the focus of TMQ does not go wayward and lose its principal aim of establishing and sustaining a quality organisation. Jablonski (1992: 24-30) postulates six (6) principles of TQM requisite for effective implantation in organisations.

1) Customer focus: TQM relates to both the internal customers (employees in an organisation) and the external customers (individuals or organisations who receive the goods and services). There is a heightened awareness of all the customers. The internal customers must contribute their knowledge and ideas in the production of goods and services, to ensure that the external customers receive the best quality.

2) $\boldsymbol{A}$ focus on process as well as results: TQM uses deficient results or unmet expectations as symptoms or indicators that sometimes is amiss with the process that produced them; hence this helps in rectifying the status quo.

3) Prevention versus Inspection: TQM introduces a structured approach to problem solving and makes the necessary investment to understand the process and sources of process variation. Thereafter, process controls are provided to ensure that every product and service meets the acceptable and predicable quality.

4) Mobilising expertise of the Workforce: TQM creates new and innovative ways to recognize individuals for their efforts. The workforce represents a tremendous wealth of knowledge and opportunity to improve the way business is conducted, increase profitability and reduce costs. The TQM approach mobilizes the expertise of the workforce in a very positive way for the mutual benefit of everyone concerned.

5) Fact Based Decision Making: the TQM approach recognizes everyone in the organisation that is effectively involved in the process, including the executive, management, workforce and customers. TQM advocates that everyone can contribute positively towards a mutually beneficial solution; and 
6) Feedback: this principle allows the other five principles to flourish. TQM encourages robust communication. It also highlights the critical importance of feedback. This involves the provision of honest feedback with an obvious and sincere desires to assist people improve their performance.

The article finally extrapolates highlights from these principles to the practical functioning of the SAPS with a view to provide a myriad of TQM principles to be considered by SAPS Management that could serve as a catalyst for an improved policing service in SA.

\section{Others}

Hansen (2008) argues that TQM ensures that quality improvement is managed sustainably; that everyone involved in the organisation is taking an active part in the achievement of quality products and services, further identifying that the problem with managing quality in an organisation lies with the process and not the people as most individuals may perceive. The responsibility of quality should be inherent to every employer, and prevention is better than cure when it comes to quality improvement problems. In a TQM conscious organisation, quality should be measurable and measured, constantly and continuously improved and be defect free; quality is also dependent on goals setting, committed management, proper cost management and accurate planning and organisation for quality improvement. Hansen's views focus on the issue of continuous provision of quality goods and services which is a process that must be led by management.

Hashmi (2008), in his article, Introduction and Implementation of TQM, provides another view on the principles of TQM, as follows:

- Management commitment: involves planning, driving and directing by management; deployment: support and participation by management; review and checks to be done.

- Employee empowerment: involves training; suggestion scheme; measurement of performance of employees and recognition; and establishment of excellence teams. 
- Fact-based decision making: involves team orientated problem solving; and use of statistical tools.

- Continuous improvement: involves the establishment of excellence teams; and involves attaining, maintaining and improving standards.

- Customer focus. involves involving servicing of internal customers; no compromise on quality; and that standards are driven by the customers.

Hashmi advocates a huge drive towards satisfying the customer, ultimately through intensified efforts both my management and its employees. There is no compromise on quality, as the quality standards are determined by the customers ultimately.

\section{The Implementation Phases of Total Quality Management}

Jablonski (1992:59-60) proposes a five-phase approach to the effective implementation of TQM in organisations. These chronological phases can serve as a starting point for the implementation and substance of TQM in organisation which value customers and view quality products and services as the means of expanding their customer bases, as well as retaining and boasting customer loyalty. These are discussed as follows:

- Phase 1: Preparation: involves the development of the organisation's vision statement, the setting of corporate goals and objectives and the drafting of corporate strategic plans. The phase is concluded with the commitment of resources that are requisite for effective implementation of TQM.

- Phase 2: Planning: involves the laying of a foundation for the process of change in an organisation. The top management commences the planning process which includes the development of an implementation plan, commitment of resources and ensuring that the plan becomes a reality.

- Phase 3: Assessment: consists of surveys, evaluations, questionnaires and interviews throughout the organisation, with a focus on individual and group perception of the organisation's strengths and weaknesses. Pivotal to this phase is establishing the agreed upon channel of communication that drives this process. 
- Phase 4: Implementation: involves the training and development of managers; further, top management authorises teams to conduct evaluations with a view to improve processes and implement change processes.

- Phase 5: Diversification: encourages the involvement of other groups within the structures of the organisation through active participation, where experiences are shared with others by networking through professional associations, local community groups or other interest groups.

The preceding literature review captured the quintessence of international approaches to total quality management; this provides a fair benchmark against which the case for the South African Police Service will be considered. The rationale for such consideration is to provide the SAPS Management with a myriad of recommendations to be considered to promote an improved policing service to the customers its serves.

\section{A Synoptical View of the South African Police Service}

\section{Constitutional Mandate and Objectives}

The Constitutional mandate of the South African Police Service is reflected in Section 205(3) of the Constitution of the Republic of South Africa, 1996 (Act No. 108 of 1996), which lays down that the SAPS has a responsibility to:

1) prevent, combat and investigate crime;

2) maintain public order;

3) protect and secure the inhabitants of the Republic and their property;

4) uphold and enforce the law;

5) create a safe and secure environment for all people in South Africa;

6) prevent anything that may threaten the safety or security of any community;

7) investigate any crimes that threaten the safety or security of any community;

8) ensure criminals are brought to justice; and

9) participation in efforts to address the causes of crime.

The objects of policing inform the department's key programmes, otherwise referred to as the financial programme structure. The SAPS has five departmental/financial programmes, which have specific purposes and defines the intended impact of the programme. In this regard therefore, resources are allocated to the five departmental 
programmes and the independent performance is also measured similarly. Funding is made available to the department as voted funds and is apportioned in terms of the programme structure. The responsible programme managers are held responsible for their financial performance against the allocated budgets that are made available at the beginning of each financial year.

A detailed description of the five (5) departmental programmes of the SAPS is depicted in Table 1 below.

Table 1: Annual Performance Plan, SAPS 2014/15

\begin{tabular}{|c|c|c|}
\hline Programme & Purpose \& Objective & Sub-Programmes \\
\hline 1. Administration & $\begin{array}{l}\text { - Develop departmental policy; } \\
\text { - Manage the department, including } \\
\text { administrative support; } \\
\text { - Support services, incl, IT, capital works and } \\
\text { property management; and } \\
\text { - Provides training of personnel }\end{array}$ & $\begin{array}{l}\text { - Minister; } \\
\text { - Deputy Minister; } \\
\text { - Management; and } \\
\text { - Corporate Services }\end{array}$ \\
\hline 2. Visible Policing & $\begin{array}{l}\text { - Enable police stations to preserve safety } \\
\text { and security; } \\
\text { - Provide for specialized interventions; and } \\
\text { - Policing of South Africa's borderlines. }\end{array}$ & $\begin{array}{l}\text { - Crime Prevention; } \\
\text { - Borderline Security; } \\
\text { and } \\
\text { - Specialised } \\
\text { Interventions }\end{array}$ \\
\hline $\begin{array}{l}\text { 3. Detective } \\
\text { Services }\end{array}$ & $\begin{array}{l}\text { - Enable the investigation work of the SAPS; } \\
\text { - Provide support to investigators in terms of } \\
\text { forensic evidence and the Criminal Record } \\
\text { Centre; } \\
\text { - Contribute to the successful prosecution of } \\
\text { crime, by investigating, gathering and } \\
\text { analyzing related evidence. }\end{array}$ & $\begin{array}{l}\text { - Crime Investigations; } \\
\text { - Criminal Record } \\
\text { Centre; and } \\
\text { - Forensic Science } \\
\text { Laboratory. }\end{array}$ \\
\hline $\begin{array}{l}\text { 4. Crime } \\
\text { Intelligence }\end{array}$ & $\begin{array}{l}\text { - Manage crime intelligence; } \\
\text { - Analyse crime information; } \\
\text { - Provide technical support for crime } \\
\text { prevention operations and for } \\
\text { investigations; } \\
\text { - Contribute to the neutralization of crime by }\end{array}$ & $\begin{array}{l}\text { - Crime Intelligence } \\
\text { Operations; } \\
\text { - Intelligence and } \\
\text { Information } \\
\text { management }\end{array}$ \\
\hline
\end{tabular}




\begin{tabular}{|c|c|c|}
\hline & $\begin{array}{l}\text { gathering, collating and analyzing } \\
\text { intelligence and information, which leads to } \\
\text { actionable policing activity. }\end{array}$ & \\
\hline $\begin{array}{l}\text { 5. Protection and } \\
\text { Security }\end{array}$ & $\begin{array}{l}\text { - Provide protection and security service to } \\
\text { all identified dignitaries and government } \\
\text { interests; } \\
\text { - Minimise security violations by protecting } \\
\text { foreign and local prominent people; and } \\
\text { - Securing strategic interests. }\end{array}$ & $\begin{array}{l}\text { - VIP Protection Services; } \\
\text { - Static and Mobile } \\
\text { Security; } \\
\text { - Ports of Entry - } \\
\text { Security and Exit; } \\
\text { - Government Security } \\
\text { Regulator } \\
\text { - Rail Police; } \\
\text { - Operational Support }\end{array}$ \\
\hline
\end{tabular}

\section{The Planning Process of the SAPS}

The SAPS develops an Annual Performance Plan (APP) which serves as the planning document for each financial year; further serving as a useful tool to implement quality policing services. The planning Information includes:

- identification of key departmental objectives;

- development of programme priorities, outputs;

- service delivery indicators, and set targets.

The implementation strategies include:

- the prevention of police killings and attacks strategy;

- corruption and fraud prevention strategy;

- the risk management strategy;

- service delivery improvement programmes, and

- guidelines for the development of operational plans at lower levels. 
Total Quality Management (TQM): A Catalyst for Service Delivery in the SAPS 17

\section{Critical Examination of the Implementation of TQM Principles in SAPS Operations and Recommendations for Reflection}

An examination of the practical implementation of TQM principles in the SAPS, as advanced by Jablonski (1992:24-30), may provide the need for further refinement and possibly reorganisation of specific activities that may yield different outcomes.

Customer focus: TQM relates to both the internal customers (employees in an organisation) and the external customers (individuals or organisations) who receive the goods and services. Internally, the SAPS manage its employees by several instruments, namely, Code of Conduct, Standing Orders, National Instructions, and so forth. Externally, the establishment of community police forums (CPF) at all police stations nationally is indicative of the organisation's commitment to customer focus. The CPF is responsible for the joint management of the police station and its allocated resources. There is a joint effort in developing policing strategy in the relevant area. There is a heightened awareness of all the customers. The police officials also contribute their knowledge and ideas in the rendering of an effective police service, to ensure that the community receives the best quality service. The SAPS has extended its stakeholder engagement beyond the community; this includes civil society, faith based organisations and the international community. The focus of this principle is the customer, and as such, the customer is most appropriately positioned to indicate if this is in fact the case. It is thus recommended that internal and external customer satisfaction surveys be analysed and its findings used by SAPS management to develop strategies and action plans that seeks to continuously improve citizen satisfaction of living in a safe and crime free society.

$\boldsymbol{A}$ focus on process as well as results: TQM uses deficient results or unmet expectations as symptoms or indicators that sometimes is amiss with the process that produced them. The National Commissioner of the SAPS has established a Crime Combating Forum (CCF), which is established at every police station in South Africa at provincial and national levels. The CCF convenes daily at all levels within the SAPS, examining and deliberating on all the shortfalls and weaknesses that may have been identified at the time, with the aim of improving the policing function. Although much effort and planning around the CCF and other forums of this nature take place on a continuous basis, serious crime, in aggregate, remains on the increase. The SAPS management may re-evaluate the science of its policing policies and processes on a continuous basis to 
ensure success thereof, as the key question remains, "Why has serious crime remain high despite the implementation of the SAPS Operational Plans, policies and processes?"

Prevention versus Inspection: TQM introduces a structured approach to problem solving and makes the necessary investment to understand the process and sources of process variation. Thereafter, process controls are provided to ensure that every product and service meets the acceptable and predicable quality. The SAPS has agreed to, among others, reduce all contact crimes by 7\%. This target was cascaded to the lowest level of management in the SAPS, with a view to ensure that a quality and acceptable policing service is being rendered to the public. The target of $7 \%$ was reduced by government in subsequent years, thus more effort in this regard may be required. The planning conducted at the different levels, including the SAPS 5 year Strategic Plan; annual performance plans; programme plans; operational plans; and project plans must be interrogated through diagnostic assessments at implementation levels with a view to identify further strategic interventions requisite to achieve the set targets. If plans are designed with acceptable quality standards and consulted with relevant role-players, then the chances for success will be high, the management could focus on implementation and monitoring of a well-designed plan.

Mobilising expertise of the Workforce: TQM creates new and innovative ways to recognize individuals for their efforts. The workforce represents a tremendous wealth of knowledge and opportunity to improve the way business is conducted, increase profitability and reduce costs. The TQM approach mobilizes the expertise of the workforce in a very positive way for the mutual benefit of everyone concerned. The SAPS has introduced an incentive and reward scheme. This incentive mobilizes and motivates the workforce forward into rendering effective quality services to the clients. Despite these initiatives, the SAPS has in recent the past experienced low morale and poor service delivery amongst its ranks, thus leading to ill-discipline and unprofessionalism. In light of this, it is recommended that SAPS re-evaluates its current incentive and reward schemes, including promotional processes to give recognition for pools of excellence within the organisation.

Fact Based Decision Making: TQM recognizes everyone in the organisation that is involved in the process, including the executive, management, workforce and customers. TQM advocates that everyone contributes positively towards a mutually beneficial 
solution. This involves understanding the work process, identifying the central causes of the problems and gathering information that will assist the work process. The SAPS recognizes various role-players within the organisation. Several retired provincial commissioners were recalled to form the Special Advisory Committee (SAP) to the National Commissioner, to assist with crucial decision making processes and policy formulation. The National Commissioner of Police has recently provided for the establishment of a Research Institute within the SAPS structure. It is proposed that the unit be adequately resourced to provide well-structured research reports/findings prior to policy changes and or significant decisions being made. This unit will undoubtedly contribute significantly to the successful development of policing policies and strategies that will assist in the reduction of crime levels in South Africa.

Feedback: TQM encourages robust communication. TQM highlights the critical importance of feedback. This involves the provision of honest feedback with an obvious and sincere desires to assist people improve their performance. The Community Service Centres (CSC) of the SAPS has introduced the customer satisfaction questionnaires. This enhances feedback as it provides a useful tool in assisting the SAPS remain relevant and appropriate in its service delivery. Further, through the CPF structures, feedback on issues relating to poor policing issues is raised with the relevant station management. The national and provincial management teams meet regularly with station management teams to review their performance based on feedback from parliament, interest groups, the community and the department internally as well. Most South Africans do not feel safe in the areas where they reside and work and hence has a negative perception on the functioning of the SAPS. These sentiments have been evidenced in the actual crime statistics, where generally crime is on the increase. Further, there have been many calls from various formations that crime statistics be released more frequently to the public. The feedback mechanisms between communities and police must be strengthened and positive action must follow these engagements. It is recommended that more effort must be made to conduct a wider scope of victim surveys and more meaningful feedback to members of the communities relating to progress on cases being investigated. 


\section{Concluding Remarks}

Total Quality Management is part of a holistic approach to progress in any organisation. Every organisation that commits itself to total quality, unlocks energy in management and the workforce. TQM has the potential to transform organisational operations by liberating employees to become more truly themselves and more creative (Bank, 1992:195). Dale and Bunney (1999:270) argue that service excellence is the hallmark of any successful organisation. However, in modern society it is difficult to identify excellent or world-class performing organisations as the few will most probably represent an expression of a maturing exponent of TQM. Organisations desiring to be successful in retaining their valuable customers may consider applying TQM principles effectively in the management of the quality of their commodities (products and services); this will eventually result in success, maturity and quality service delivery levels.

This article has presented some literature on TQM by the founding fathers or widely accepted authorities on the topic with a view to provide some basis to critically evaluate the implementation of its principles in the SAPS. Finally, the recommendations provided are intended to strengthen the arm of management with practical ways on achieving quality services, focussing on the customer and improving feedback mechanisms. The effective implementation of TQM principles within the SAPS may contribute significantly to crime reduction in South Africa, thus creating the safe and secure environment that all citizens dream of.

\section{List of References}

- Bank, J. 1992. The essence of Total Quality Management. London: Prentice Hall International.

- Dale, B. and Bunney, H. 1999. Total Quality Management Blueprint. Manchester: Blackwell Publishers.

- Hansen, DA. 2008. Total Quality Management (TQM) Tutorial. http://www.amazon.com/TQM. (Accessed: 2014/09/01). 
Total Quality Management (TQM): A Catalyst for Service Delivery in the SAPS 21

- Hashmi, K. 2008. Introduction and Implementation of TQM. Six Sigma: http://www.isixsigma.com/methodology/total-quality-management-tqm/introduction-andimplementation-total-quality-management-tqm/. (Accessed: 2014/09/02).

- Jablonski, JR. 1992. Implementing TQM. California: Pfeiffer \& Company.

- Packard, T. 1995. TQM and Organisational Change \& Development. San Diego: Rockefeller College Press.

- Republic of South Africa 1996. Constitution of the Republic of South Africa, 1996 (Act 108 of 1996). Pretoria: Government Printer

- Republic of South Africa 1999. Public Finance Management Act, 1999. (Act No 1 of 1999) as amended by Act 29 of 1999. Pretoria: Government Printer

- $\quad$ Republic of South Africa 1995. South African Police Service Act, 1995 (Act 68 of 1995). Pretoria: Government Printer

- Smit, PJ, Cronje, GJ, Brevis, T. Vrba, MJ. 2007. Management Principles- $A$ contemporary edition. Cape Town: Juta \& Co.

- South African Police Service. 2014. Annual Performance Plan: 2014/15. Pretoria.

- Wikipedia. 2013. Total Quality Management. www.wilkipedia.org/wiki/Total Quality Management (Accessed: 2014/09/03).

AUTHOR'S CONTACT:

\section{REDDY Michael}

Finance\& Administration services

Directorate for Priority crime investigation

South African Police Service

Email: ReddyM@saps.gov.za 